\title{
Possible immunotherapeutic potentiation with D-Fraction in prostate cancer cells
}

\author{
Paul Pyo, Brandon Louie, Srinivas Rajamahanty, Muhammad Choudhury \\ and Sensuke Konno*
}

Address: Department of Urology, New York Medical College, Valhalla, NY 10595, USA

Email: Paul Pyo - pyo40@aol.com; Brandon Louie - brandon_louie@hotmail.com; Srinivas Rajamahanty - rajamahanty14@gmail.com; Muhammad Choudhury - muhammad_choudhury@nymc.edu; Sensuke Konno* - sensuke_konno@nymc.edu

* Corresponding author

Published: 4 December 2008

Journal of Hematology \& Oncology 2008, I:25 doi:10.1 I86/I756-8722-I-25
Received: 31 October 2008

Accepted: 4 December 2008

This article is available from: http://www.jhoonline.org/content/I/I/25

(c) 2008 Pyo et al; licensee BioMed Central Ltd.

This is an Open Access article distributed under the terms of the Creative Commons Attribution License (http://creativecommons.org/licenses/by/2.0), which permits unrestricted use, distribution, and reproduction in any medium, provided the original work is properly cited.

\begin{abstract}
Background: Prostate cancer remains the most common malignancy among elderly men and the second leading cause of cancer death in the United States. Although several conventional therapies are currently available, they have a low efficacy and the more effective treatment modalities need to be established. Interferons (IFNs) are one of such options known as immunotherapy and demonstrated their antitumor effects on certain cancer types. Yet such antitumor activity should be improved or potentiated to have the satisfactory outcomes. In fact, combination therapy has been proposed as an alternative approach and is being underway in human and animal studies. Accordingly, we studied whether the combination of IFN- $\alpha$ and D-fraction (PDF), a bioactive mushroom extract, might potentiate anticancer activity of IFN- $\alpha$ in prostate cancer PC-3 cells in vitro.
\end{abstract}

Results: Potential effects of recombinant IFN- $\alpha_{2 b}(0-100,000 \mathrm{IU} / \mathrm{ml})$, PDF $(0-1,000 \mu \mathrm{g} / \mathrm{ml})$, or their combinations were assessed on the growth of PC-3 cells at $72 \mathrm{~h}$. Cell cycle analysis using a flow cytometer and Western blot analysis were performed to explore antiproliferative mechanism of these agents. The dose-dependent study showed that IFN- $\alpha_{2 b}$ up to $20,000(20 \mathrm{~K}) \mathrm{IU} / \mathrm{ml}$ had no significant effects, but $>60 \%$ growth reduction was attained $\leq 50 \mathrm{~K} \mathrm{IU} / \mathrm{ml}$. Similarly, PDF showed no effects up to $250 \mu \mathrm{g} / \mathrm{ml}$ but $\sim 65 \%$ growth reduction was seen at $\mathrm{I}, 000 \mu \mathrm{g} / \mathrm{ml}$. When IFN- $\alpha_{2 b}$ and PDF were combined, a relatively low concentration $(10 \mathrm{~K} \mathrm{IU} / \mathrm{ml})$ of IFN- $\alpha_{2 b}$ and PDF $(250 \mu \mathrm{g} / \mathrm{ml})$ resulted in a $\sim 65 \%$ growth reduction. This was accompanied by a $G$, cell cycle arrest, indicated by cell cycle analysis. Western blots also revealed that the $G_{1}$-specific cell cycle regulators, CDK2, CDK4, CDK6, cyclin $D_{1}$, and cyclin E, had been significantly (>60\%) down-regulated in IFN/PDFtreated cells.

Conclusion: The combination of IFN- $\alpha_{2 b}(10 \mathrm{~K} \mathrm{IU} / \mathrm{ml})$ and PDF $(250 \mu \mathrm{g} / \mathrm{ml})$ is capable of inducing a $\sim 65 \%$ reduction in PC-3 cell growth. This appears to be due to a synergistic potentiation of two agents, leading to a $G_{1}$ cell cycle arrest. Thus, it is conceivable that PDF may potentiate IFN- $\alpha_{2 b}$ activity, improving immunotherapy for prostate cancer. 


\section{Background}

Current therapy for prostate cancer (CaP), the most common malignancy in elderly men in the United States [1], is directed at exploitation of the androgen-dependent state of prostatic cancer cells. Various antiandrogens and leuteinizing hormone-releasing hormone (LHRH) agonists are useful for blocking the availability of androgen to the cancer cells [2]. However, the efficacy of these drugs is of limited duration, and patients experience an almost inevitable progression of their cancers to the fatal androgen-independent state [3]. To develop an alternative approach for controlling or preventing such disease progression, it demands in searching for agents/drugs that could effectively regulate the CaP proliferation.

Interferons (IFNs) are known to trigger multiple cellular responses including antiviral activity, growth inhibition, cell differentiation and immunoregulation [4]. Many studies have also focused on the potential antitumor effects of IFNs using both in vitro and in vivo cancer models [5]. For instance, IFNs have been widely used as immunotherapy for urological malignancies including prostate, bladder, and renal carcinomas [6-8]. Compared to chemotherapy, less or moderate side effects of IFNs have also been shown to be beneficial to cancer patients. Some encouraging data from such IFN monotherapy have been reported [9], although they are yet somewhat inconsistent and conflicting. In addition, particularly in clinical CaP cases, IFN therapy has several drawbacks such as high cost and repeated administration [6]. These disadvantages thus limit its use in clinical practice, and further exploration of improved treatment modality, e.g. combination therapy, is required.

The D-fraction (PDF), the unique proteoglucan extracted from maitake mushroom (Grifola frondosa), is the acidinsoluble, alkali-soluble and hot water-extractable fraction [10]. It structurally consists of either $\beta-1,6$-linked glucan with $\beta-1,3$ branches or $\beta-1,3$ glucan branched with $\beta$ 1,6 glucosides, having a molecular weight of $\sim 1 \times 10^{6} \mathrm{dal}-$ ton [10]. PDF has been commercially available for a variety of medical and scientific research, and a number of published and unpublished studies have thus far suggested the immunomodulatory and antitumor activities of PDF [11-13]. It has been shown in an animal model that PDF was capable of activating immune-competent cells such as natural killer cells and cytotoxic T-cells with a concomitant increase in interleukin-1 production [11], indicating stimulation of immune responses. A preventive or inhibitory activity of PDF on carcinogenesis and metastasis has also been demonstrated in mice [12], suggesting its antitumor activity. Moreover, a chemosensitizing effect of PDF has been postulated on conventional anticancer drugs being currently used [13].
Accordingly, we are interested in investigating whether the combination of IFN- $\alpha_{2 b}$ and PDF may have the potentiated growth inhibitory effects on prostatic cancer cells in vitro. Such studies may provide us with useful information on the improved efficacy of IFN therapy on prostate cancer.

\section{Results \\ Effects of IFN- $\alpha_{2 b}$ or PDF on PC-3 cell growth}

To examine the possible effects of individual IFN- $\alpha_{2 b}$ or PDF on PC-3 cell proliferation, cells were cultured with varying concentrations of IFN- $\alpha_{2 b}(0-100,000=100 \mathrm{~K} \mathrm{IU} /$ $\mathrm{ml})$ or PDF $(0-1,000 \mu \mathrm{g} / \mathrm{ml})$ for $72 \mathrm{~h}$. Such a dosedependent study showed that IFN- $\alpha_{2 b}$ had no apparent effects up to $20 \mathrm{~K} \mathrm{IU} / \mathrm{ml}$ but induced $>60 \%$ growth reduction at $50 \mathrm{~K}$ and $100 \mathrm{~K} \mathrm{IU} / \mathrm{ml}$ (Fig. 1A). Similarly, no effects of PDF was seen up to $250 \mu \mathrm{g} / \mathrm{ml}$ but a marginal $(10-20 \%)$ and significant ( $65 \%)$ growth reduction was observed at 500 and $1,000 \mu \mathrm{g} / \mathrm{ml}$, respectively (Fig. 1B). Thus, these studies demonstrate that both IFN- $\alpha_{2 b}$ and PDF are capable of inhibiting PC-3 cell growth, although PDF required rather a high concentration $(1,000 \mu \mathrm{g} / \mathrm{ml})$ to be effective.

\section{Synergistic growth inhibitory effects of IFN- $\alpha_{2 b}$ and PDF}

To examine whether combinations of IFN- $\alpha_{2 b}$ and PDF may exhibit the enhanced growth inhibitory effects, the varying concentrations of IFN- $\alpha_{2 b}$ and PDF were combined and their effects on PC-3 cell growth were assessed. Such results showed that combinations of $10 \mathrm{~K} \mathrm{IU} / \mathrm{ml}$ of IFN- $\alpha_{2 \mathrm{~b}}$ and 100 or $250 \mu \mathrm{g} / \mathrm{ml}$ of PDF resulted in nearly $40 \%$ or $65 \%$ growth reduction, respectively (Fig. 2 ). These enhanced inhibitory effects are most likely attributed to a synergistic potentiation of two agents, because the given concentrations of IFN- $\alpha_{2 b}(10 \mathrm{~K} \mathrm{IU} / \mathrm{ml})$ and PDF (100 or $250 \mu \mathrm{g} / \mathrm{ml}$ ) by itself had no such effects (Fig. 1AB). Thus, IFN $-\alpha_{2 b}$ and PDF appear to work synergistically.

Effects of IFN- $\alpha_{2 b}$, PDF, or their combination on cell cycle To better understand the underlying mechanism of such a synergistic growth inhibition induced by the IFN- $\alpha_{2 b} / P D F$ combination, their possible effects on the cell cycle were explored next. Cells were treated with IFN- $\alpha_{2 b}(10 \mathrm{~K} \mathrm{IU} /$ $\mathrm{ml})$, PDF $(250 \mu \mathrm{g} / \mathrm{ml})$, or their combination for $72 \mathrm{~h}$, and they were subjected to cell cycle analysis using a flow cytometer. IFN- $\alpha_{2 b}$ or PDF alone had little effects similar to cell cycle phase distribution in control cells; however, the IFN- $\alpha_{2 b} /$ PDF combination caused an $\sim 63 \%$ decrease in cell number in the $S$ phase with a concomitant $55 \%$ increase in the $\mathrm{G}_{1}$-phase cell population compared to those in controls (Fig. 3). These results indicate that the IFN- $\alpha_{2 b} /$ PDF combination causes a blockage of cells entering from the $G_{1}$ to the $S$ phase, increasing cell number in the $G_{1}$ phase. This accumulation of cells in the 
A

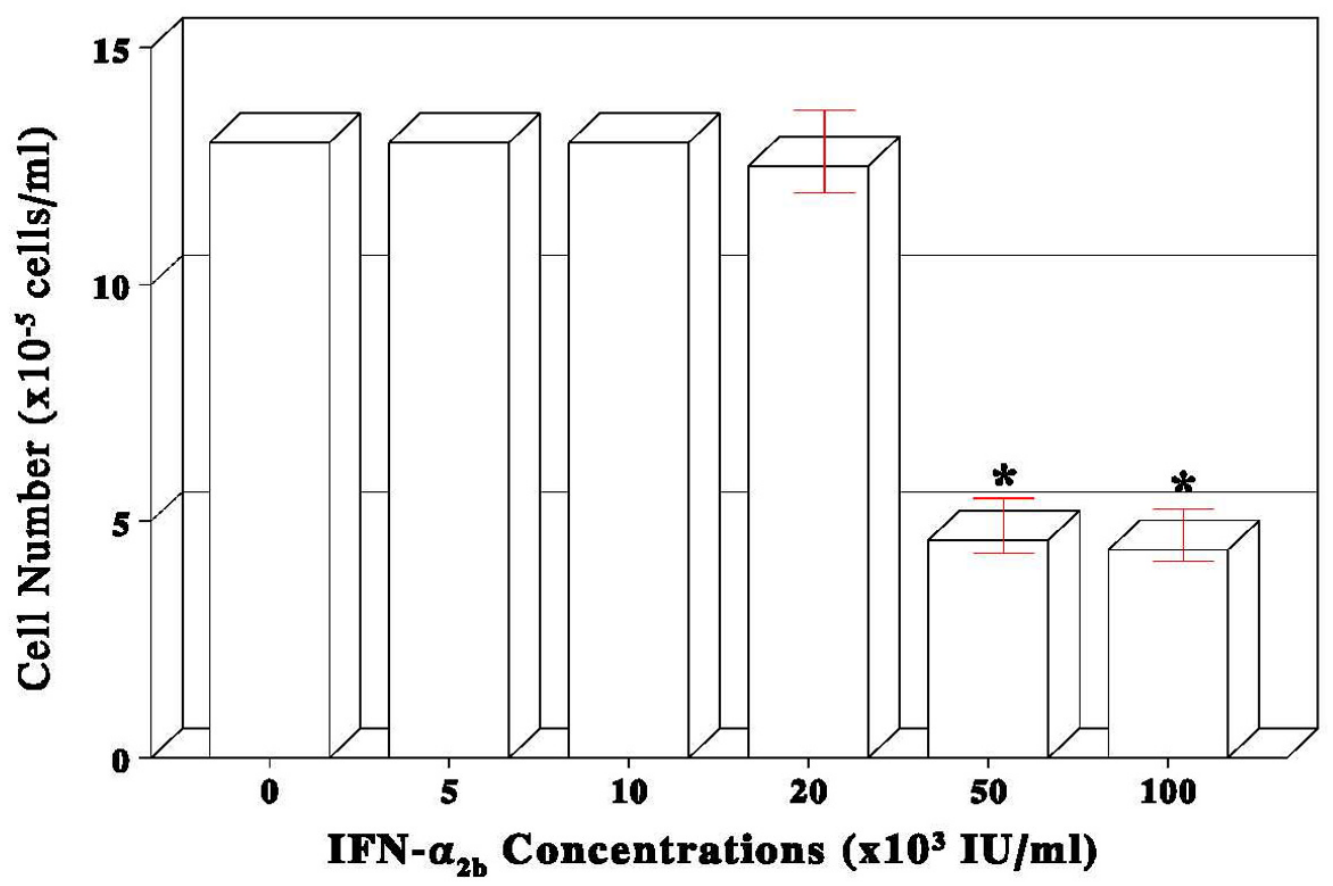

B

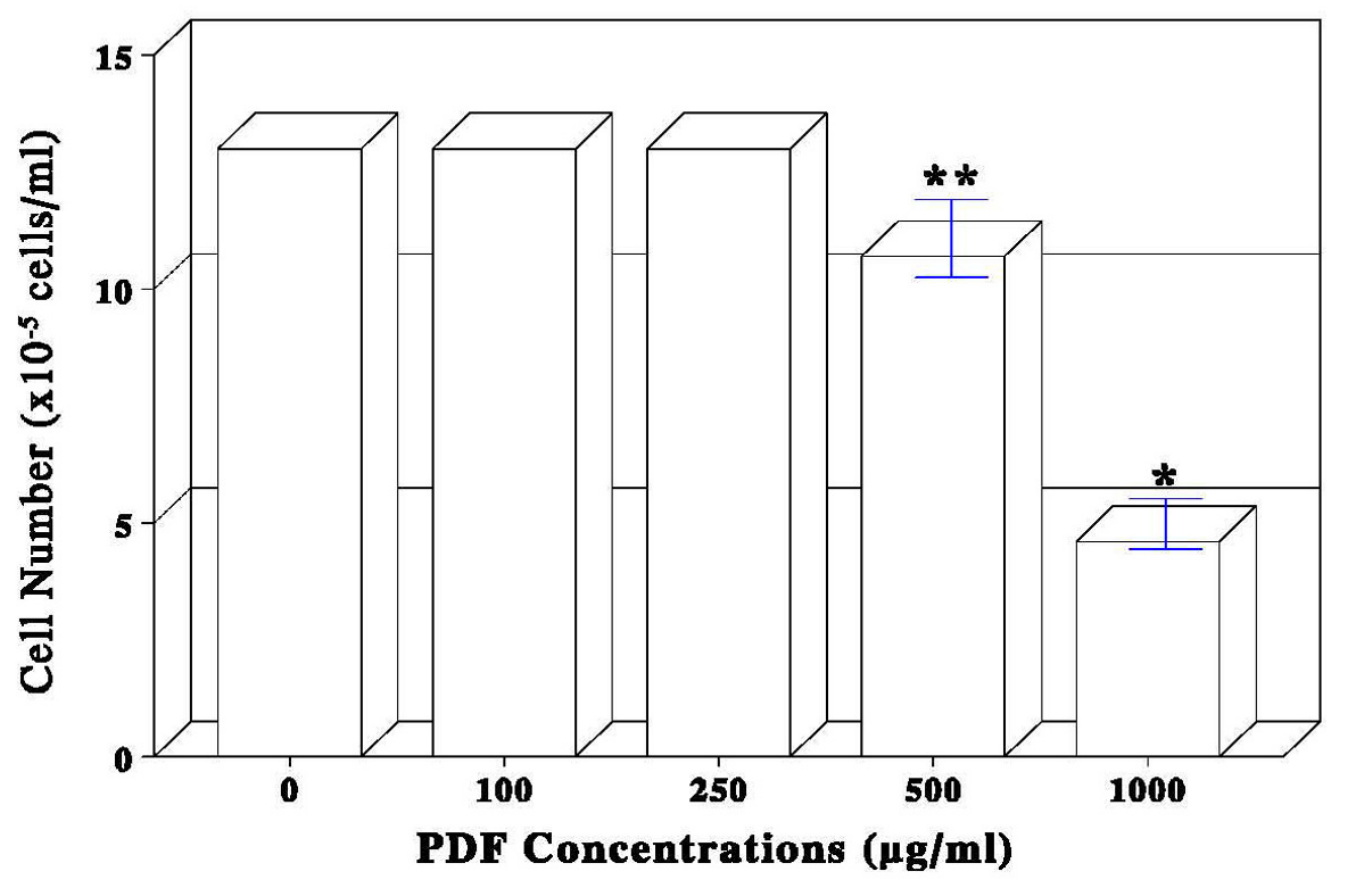

Figure I

Dose-dependent effects of IFN- $\alpha_{2 b}$ or PDF on PC-3 cell growth. PC-3 cells were cultured with varying concentrations of either IFN- $\alpha_{2 b}(0-100,000 \mathrm{IU} / \mathrm{ml})$ or PDF $(0-1,000 \mu \mathrm{g} / \mathrm{ml})$ as indicated, and viable cell numbers in IFN- $\alpha_{2 b}$-treated $(\mathbf{A})$ or PDF-treated (B) cases were determined at $72 \mathrm{~h}$. All data represent mean \pm SD (standard deviation) from three separate experiments $\left(*_{p}<0.02 ; * *<0.08\right)$. 


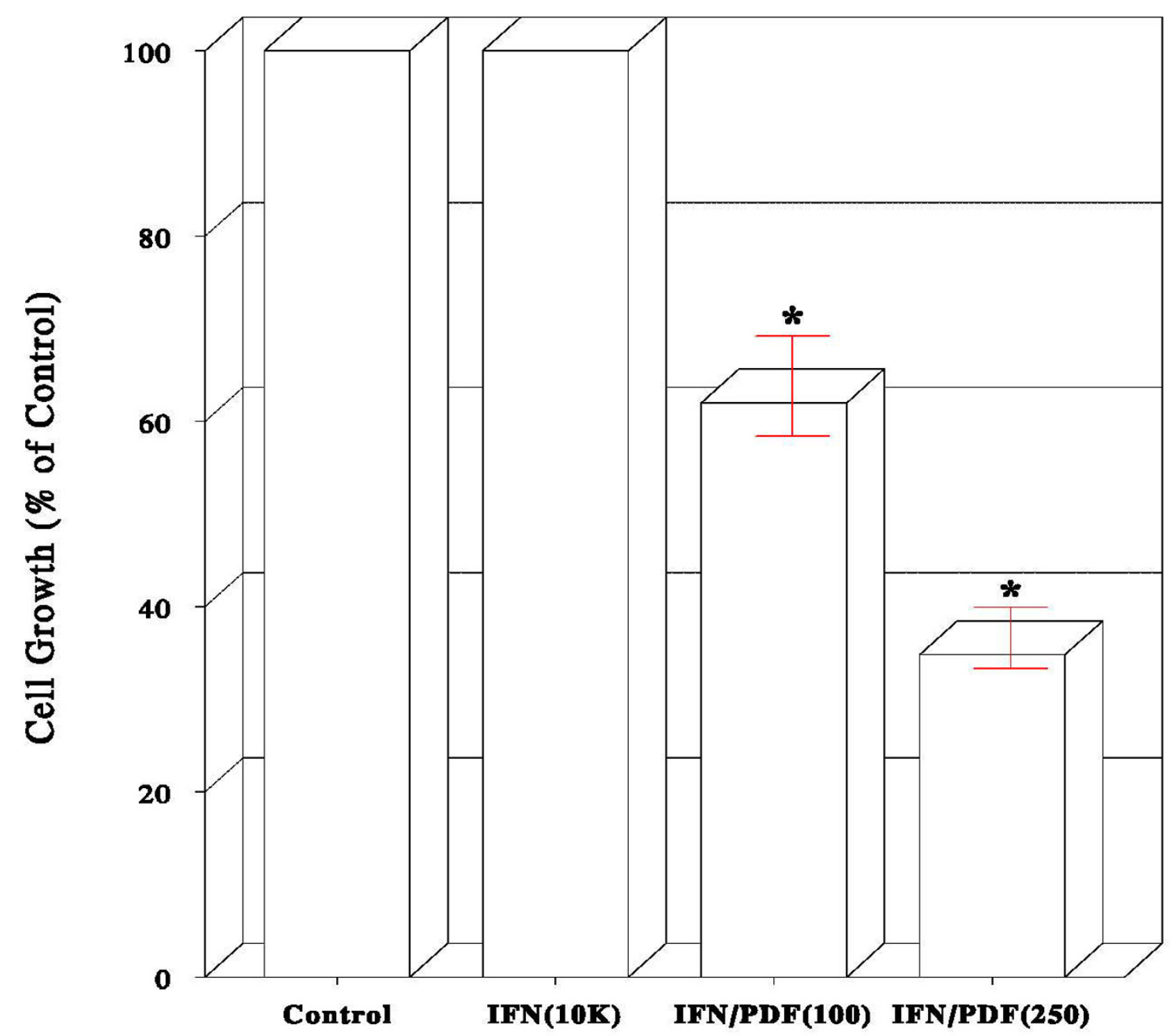

Figure 2

Effects of combinations of IFN- $\alpha_{2 b}$ and PDF on cell growth. Cells were cultured with varying concentrations of IFN$\alpha_{2 b}$ /PDF combination for $72 \mathrm{~h}$, and cell growth was assessed by the \% of viable cell number relative to that in control (I00\%). Cell growth in control, IFN- $\alpha_{2 b}(10 \mathrm{~K} \mathrm{IU} / \mathrm{ml})$-treated, or IFN- $\alpha_{2 b}(10 \mathrm{~K}) / \mathrm{PDF}(100 \mu \mathrm{g} / \mathrm{ml})$-treated, or IFN- $\alpha_{2 b}(10 \mathrm{~K}) / \mathrm{PDF}(250)$ treated cells is shown. The data are mean \pm SD from three independent experiments $(* p<0.05)$.

$G_{1}$ phase is known as a $G_{1}$ cell cycle arrest [14], which feasibly leads to the growth inhibition.

\section{Down-regulation of cell cycle regulators by IFN- $\alpha_{2 b} / P D F$ combination}

To confirm a $G_{1}$ cell cycle arrest induced by the IFN- $\alpha_{2 b}$ $(10 \mathrm{~K} \mathrm{IU} / \mathrm{ml}) / \mathrm{PDF}(250 \mu \mathrm{g} / \mathrm{ml})$ combination, we also examined its effects on the specific cell cycle regulators for the $\mathrm{G}_{1}-\mathrm{S}$ phase transition such as CDK2, CDK4, CDK6, cyclin $\mathrm{D}_{1}$, and cyclin E [14]. After 72-h treatment, cell lysates were prepared and subjected to Western blot analysis, as described in Materials and Methods. Cellular expressions of these cell cycle regulators following IFN$\alpha_{2 b} /$ PDF treatment were all significantly reduced by $>60 \%$ (quantitated by densitometric scanning), compared to those in controls (Fig. 4). Such a down-regulation of these cell cycle "promoters" (to be more properly described) further supports a blockage of $\mathrm{G}_{1}-\mathrm{S}$ phase transition. Taken together, these studies are highly suggestive that a 


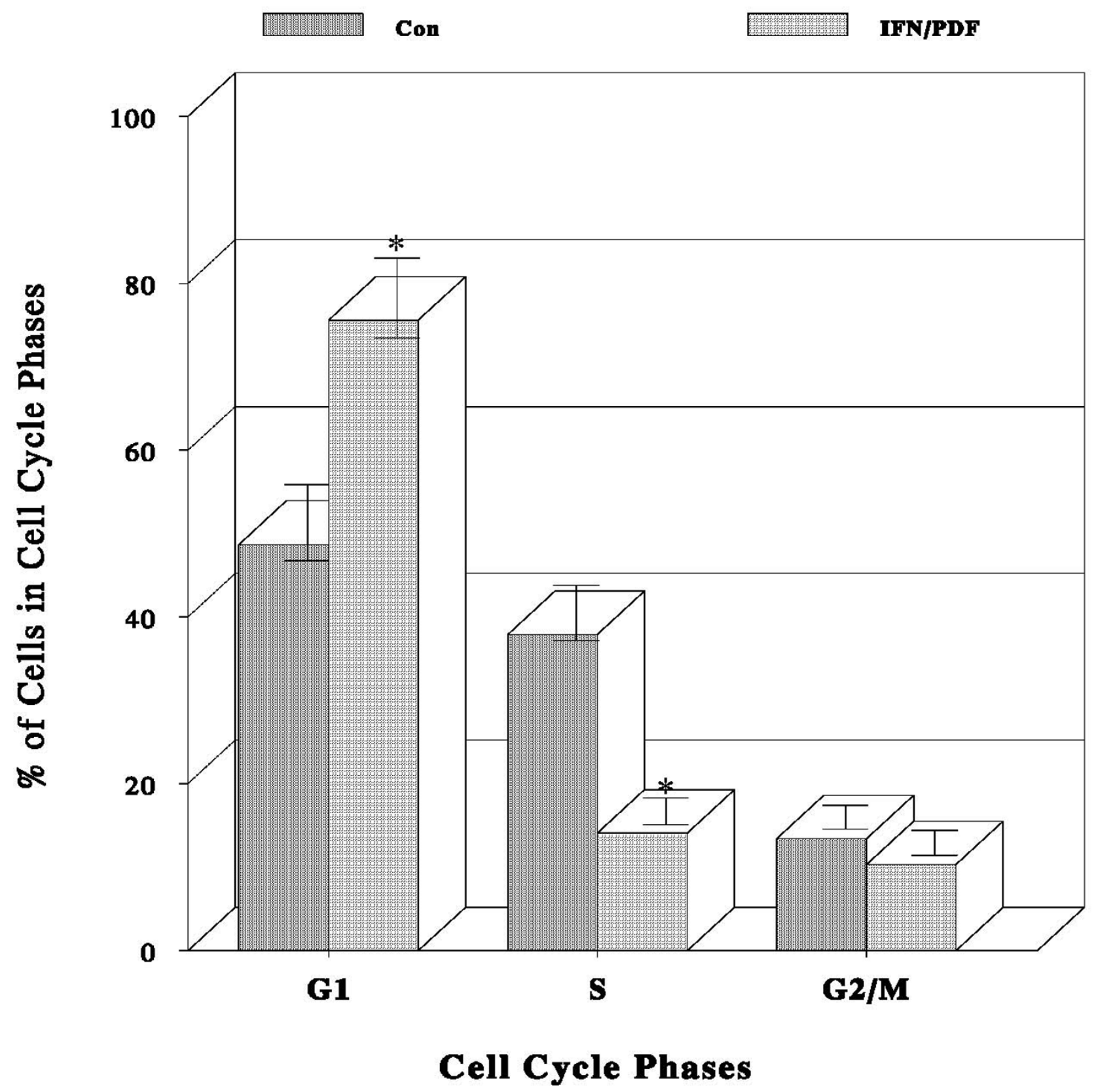

Figure 3

Cell cycle analysis. Cells were cultured with IFN- $\alpha_{2 b}(10 \mathrm{~K} \mathrm{IU} / \mathrm{ml})$, PDF $(250 \mu \mathrm{g} / \mathrm{ml})$, or their combination for $72 \mathrm{~h}$, and they were subjected to cell cycle analysis as described in Materials and Methods. IFN- $\alpha_{2 b}$ or PDF alone had little effects on cell cycle phase distribution similar to that in control cells. However, the IFN/PDF combination resulted in significant changes $(* p<0.05)$ in cell populations in the $G_{1}$ and $S$ phases compared to controls, as shown here.

$\mathrm{G}_{1}$ cell cycle arrest is the critical event taking place in the IFN- $\alpha_{2 b} /$ PDF-induced growth inhibition.

\section{Discussion}

IFNs belong to the family of cytokines and are capable of activating a cascade of intracellular pathways that regulate cell growth/differentiation and also produce antiviral and immunological responses [4,15]. Particularly, the antitumor potential of IFNs gained a great attention and has been extensively investigated for over two decades. Some early studies showed that IFNs had induced regression of tumors in a significant number of patients with metastatic 


\section{Control IFN/PDF}

\section{$\mathrm{CDK} 2$}

CDK4

\section{CDK6}

\section{Cyclin $D_{1}$}

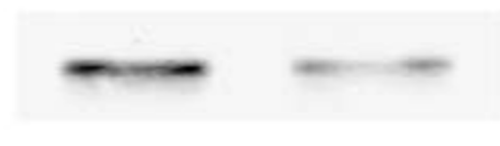

\section{Cyclin E}

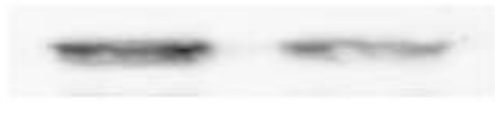

\section{Figure 4}

Western blot analysis. After cells were treated with or without the combination of IFN- $\alpha_{2 b}(10 \mathrm{~K} \mathrm{IU} / \mathrm{ml})$ and PDF $(250 \mu \mathrm{g} / \mathrm{ml})$ for $72 \mathrm{~h}$, cell lysates $(7 \mu \mathrm{g})$ obtained from control and the IFN- $\alpha_{2 b} /$ PDF-treated cells were analyzed for CDK2, CDK4, CDK6, cyclin $D_{1}$, and cyclin $E$ using Western blots. Significantly ( $>60 \%)$ reduced expressions of all these regulators following the IFN/PDF treatment are apparent on the blots.

breast cancer, low-grade lymphoma, and multiple myeloma [16]. However, the efficacy of IFNs on tumor regression was also found to vary with cancer types [17], and some data from specific IFN monotherapy indeed showed such discrepancy. Moreover, a high cost and repetitive administration of IFN (monotherapy) somewhat limit its clinical utility. Accordingly, reducing a cost while improving the efficacy of IFNs, "combination" therapy has been proposed and promoted.

In the present study, we explored such combination therapy as an alternative approach for prostate cancer immunotherapy; i.e. combination of IFN- $\alpha_{2 b}$ and D-fraction (PDF). Dose-dependent studies showed that IFN- $\alpha_{2 b} \geq 50$ $\mathrm{K} \mathrm{IU} / \mathrm{ml}$ or PDF at $1,000 \mu \mathrm{g} / \mathrm{ml}$ was capable of inducing $>60 \%$ growth reduction in prostate cancer PC-3 cells (Fig.
1). Moreover, a 65\% growth reduction was attained with the combination of $10 \mathrm{~K} \mathrm{IU} / \mathrm{ml} \mathrm{IFN-} \alpha_{2 \mathrm{~b}}$ and $250 \mu \mathrm{g} / \mathrm{ml}$ PDF (Fig. 2). This augmented growth inhibition results conceivably from a synergistic potentiation of two agents, because neither $10 \mathrm{~K} \mathrm{IU} / \mathrm{ml}$ IFN- $\alpha_{2 \mathrm{~b}}$ nor $250 \mu \mathrm{g} / \mathrm{ml}$ PDF alone has any growth inhibitory activity (Fig. 1). Thus, the relatively low concentrations of IFN- $\alpha_{2 b}$ and PDF when combined are required for their potentiated antiproliferative effects. In other words, to attain the same growth inhibitory effect ( $65 \%)$ induced by $50 \mathrm{~K} \mathrm{IU} / \mathrm{ml}$ of IFN$\alpha_{2 b}$ alone, merely " $1 / 5^{\text {th" }}(10 \mathrm{~K} \mathrm{IU} / \mathrm{ml})$ of that IFN- $\alpha_{2 b}$ would be needed when combined with PDF. It is then plausible that PDF may not only help potentiate IFN- $\alpha_{2 b}$ activity but also help cut the cost down.

We next examined the effects of IFN- $\alpha_{2 b} /$ PDF combination on the cell cycle regulation in order to explore the growth inhibitory mechanism. Cell cycle analysis revealed a $\sim 63 \%$ decrease in the S-phase cell number with a concomitant $55 \%$ increase in the $\mathrm{G}_{1}$-phase cell number following the treatment of IFN- $\alpha_{2 b} /$ PDF combination (Fig. 3 ). The resulting " $G_{1}$ cell accumulation" is termed a $G_{1}$ cell cycle arrest, accounting in part for the ultimate growth cessation. In addition, the expressions of specific $\mathrm{G}_{1}$ cell cycle regulators, such as CDK2, CDK4, CDK6, and cyclins $\mathrm{D}_{1} / \mathrm{E}$, were all markedly (>60\%) down-regulated (Fig. 4). Thus, these findings suggest that the growth inhibitory action of IFN- $\alpha_{2 b} / P D F$ combination may target primarily the $G_{1}-S$ phase transition in the cell cycle, resulting in a $G_{1}$ arrest.

Yet, it should be also noted that IFNs are known to modulate many proteins and enzymes [18], particularly specific protein kinases acting on the signal transduction pathway for cell proliferation and/or differentiation. In other words, IFNs can regulate cell growth through the signal transduction mediated by these protein kinases. Additionally, it has been documented that IFNs could induce DNA fragmentation, leading to an accumulation of small or low-molecular-weight DNA [19]. This may imply activation of a specific protein kinase called double-stranded DNA-dependent protein kinase (DNA-PK), which requires small double-stranded DNA for its activation [20]. DNA-PK is also believed to play an important role in the cell cycle regulation [21]. These information further suggest that our IFN- $\alpha_{2 b} /$ PDF combination may affect certain protein kinase(s), triggering the specific cascade events (via the signal transduction) on the cell cycle to ultimately cease cancer cell growth. Therefore, such biochemical studies are undoubtedly required and being underway in our laboratory.

In addition, it is important to further investigate whether the enhanced growth inhibitory effect of IFN- $\alpha_{2 b} / P D F$ combination observed in this in vitro study might be also demonstrated in animal study (in vivo). Such study would 
then allow us to assess the actual efficacy of IFN- $\alpha_{2 b} /$ PDF combination on prostate tumor grown in mice and to determine the effective or tolerable physiological concentrations of these agents. This will be conducted shortly as our Phase II study.

Furthermore, the safety of IFN- $\alpha_{2 b}$ or PDF in human use would be certainly concerned. IFN- $\alpha_{2 b}$ has been often used in immunotherapy for various cancer patients and its concentrations up to $5 \times 10^{6} \mathrm{IU}$ have been shown to be relatively safe and tolerable in those with prostate cancer $[9,22]$. It eventually needs to be determined how the effective concentration of $10 \mathrm{~K} \mathrm{IU} / \mathrm{ml}$ IFN- $\alpha_{2 b}$ (in combination with PDF) in this study would be extrapolated to actual patients. For PDF, early animal and clinical studies ascertained the safety of PDF without any side/adverse effects [13]. This was further supported by the fact that the U.S. Food and Drug Administration (FDA) had exempted Dfraction from a Phase I toxicology study. The FDA has also approved PDF for an Investigational New Drug (IND) application to conduct a Phase II pilot study on patients with advanced breast and prostate cancer [23]. Although such clinical trials are currently in progress, the effective concentrations of PDF yet remain to be established. Taken together, our next animal study is crucial and indisputably required for confirming the safety of IFN- $\alpha_{2 b}$ and PDF and also obtaining valid information on their effective and tolerable physiological concentrations. It may then help lead us to an ultimate clinical trial in the future.

\section{Conclusion}

In summary, the combination of IFN- $\alpha_{2 b}$ and PDF demonstrates a synergistic antiproliferative activity on prostate cancer PC-3 cells. This potentiated growth inhibition results primarily from a $G_{1}$ cell cycle arrest. Therefore, the low-dose IFN- $\alpha_{2 b} /$ PDF combination may provide an alternative, improved immunotherapy for prostate cancer, implying its clinical utility/application. It is promising but further studies are yet required.

\section{Methods \\ Cell culture}

The human prostate cancer PC-3 cells, derived from a patient with bone metastasis, were obtained from the American Type Culture Collection (Rockville, MD). Cells were maintained in RPMI-1640 medium containing 10\% fetal bovine serum, penicillin $(100 \mathrm{U} / \mathrm{ml})$, and streptomycin $(100 \mu \mathrm{g} / \mathrm{ml})$. Routinely, culture medium was changed every 3 to 4 days and the passage of cells was performed weekly. For experiments, cells were seeded in T-75 flasks or 6-well culture plates at the initial cell density of $1 \times 10^{5}$ cells $/ \mathrm{ml}$ and were cultured with recombinant interferon$\alpha_{2 \mathrm{~b}}$ (IFN- $\alpha_{2 \mathrm{~b}}$; Schering Corp., Kenilworth, NJ), D-fraction (PDF; Maitake Products, Inc., Paramus, NJ) or their com- binations. Cell numbers were then assessed at specified times using the trypan blue exclusion method.

\section{Cell cycle analysis}

A FACScan flow cytometer (Becton-Dickinson, San Jose, CA), equipped with a double discrimination module, was employed for cell cycle analysis. Approximately $1 \times 10^{6}$ cells were resuspended in $500 \mu \mathrm{l}$ of propidium iodide solution $(20 \mu \mathrm{g} / \mathrm{ml}$ propidium iodide, $0.2 \mathrm{mg} / \mathrm{ml}$ RNase, $0.2 \mathrm{mg} / \mathrm{ml}$ EDTA, $0.5 \%$ NP-40) and incubated at room temperature for $1 \mathrm{~h}$. Ten thousand nuclei were analyzed for each sample, and CellFit software was used to quantify cell cycle compartments and estimate cell cycle phase fractions.

\section{Western blot analysis}

Cell pellets from control and IFN- $\alpha_{2 b} /$ PDF-treated cells were resuspended in cell lysis buffer and cell lysates were prepared by freeze-thaw three times in liquid nitrogen. The Western blot procedure essentially followed the protocol described previously [24]. Briefly, an equal amount of proteins $(7 \mu \mathrm{g})$ from control and IFN- $\alpha_{2 b} /$ PDF-treated cell lysates was resolved by $10 \%$ SDS-PAGE (SDS-polyacrylamide gel electrophoresis) and transferred to a nitrocellulose membrane. The blot was first incubated for $90 \mathrm{~min}$ with the primary antibodies against CDK2, CDK4, CDK6, cyclin $\mathrm{D}_{1}$, or cyclin E (Santa Cruz Biotechnology, Santa Cruz, CA), followed by incubation with the appropriate secondary antibody conjugates for $30 \mathrm{~min}$. The specific immunoreactive proteins were then detected by chemiluminescence, following a vender's protocol (Kirkegaard and Perry Laboratories, Gaithersburg, MD), and quantified using a scan densitometer (Silk Scientific, Oregon, UT).

\section{Statistical analysis}

All data are presented as the mean \pm SD (standard deviation), and statistical differences between groups were assessed with the unpaired Student's $t$ test. A value of $p<$ 0.05 is considered to be significant.

\section{Competing interests}

The authors declare that they have no competing interests.

\section{Authors' contributions}

$\mathrm{PP}$ is a primary investigator in charge of performing all experiments and drafting the manuscript; BL and SR serve as assistants for PP to help set up and run experiments (cell culture, flow cytometer, and Western blots); MC is the department chairman, providing us with all his support for this project; and SK is responsible for designing experiments, analyzing the data (and statistical analysis), and editing/finalizing the manuscript. All authors read and approved the final manuscript. 


\section{Acknowledgements}

This study was supported by the Departmental Research Fund. We thank Mr. Mike Shirota (Maitake Products, Inc.) for kindly providing D-fraction (PDF).

\section{References}

I. Landis SH, Murray T, Bolden S, Wingo PA: Cancer statistics, 1999. CA Cancer J Clin 1999, 49:8-31.

2. McLeod DG: Antiandrogenic drugs. Cancer 1993, 71:1046-1049.

3. Davies $P$, Eaton CL: Regulation of prostate growth. J Endocrinol 1991, I31:5-17.

4. Hobeika AC, Etienne W, Cruz PE, Subramaniam PS, Johnson HM: IFN $\gamma$ induction of $\mathrm{p} 2 \mathrm{I}$ wafl in prostate cancer cells: Role in cell cycle, alteration of phenotype and invasive potential. Int J Cancer 1998, 77:138-145.

5. Sica G, lacopino F, Recchia F: Interferon and hormone sensitivity of endocrine-related tumors. Anticancer Drugs 1996, 7:150-160.

6. Harris DT, Matyas GR, Gomella LG, Talor E, Winship MD, Spitler LE, Mastrangelo MJ: Immunologic approaches to the treatment of prostate cancer. Semin Oncol 1999, 26:439-447.

7. Glashan RW: A randomized controlled study of intravesical alpha-2b-interferon in carcinoma in situ of the bladder. J Urol 1990, | 44:658-66|.

8. Bukowski RM: Cytokine therapy for metastatic renal cell carcinoma. Semin Urol Oncol 200I, 19:148-154.

9. Van Haelst-Pisani CM, Richardson RL, Su J, Buckner JC, Hahn RG, Frytak S, Kvols LK, Burch PA: A phase II study of recombinant human alpha-interferon in advanced hormone-refractory prostate cancer. Cancer 1992, 70:2310-2312.

10. Mizuno T, Zhuang C: Maitake, Grifola frondosa: pharmacological effects. Food Rev Int 1995, I I: I35- I 49.

II. Adachi K, Nanba H, Kuroda H: Potentiation of host-mediated antitumor activity in mice by $\beta$-glucan obtained from Grifola frondosa (maitake). Chem Pharm Bull (Tokyo) 1987, 35:262-270.

12. Nanba H: Activity of Maitake D-fraction to inhibit carcinogenesis and metastasis. Ann NY Acad Sci 1995, 768:243-245.

13. Nanba $\mathrm{H}$ : Maitake D-fraction: Healing and preventive potential for cancer. J Orthomol Med 1997, I 2:43-49

14. Reddy GP: Cell cycle: Regulatory events in $\mathbf{G}_{1}-\mathbf{S}$ transition of mammalian cells. J Cell Biochem 1994, 54:379-386.

15. Gutterman JU: Cytokine therapeutics: Lessons from interferon $\alpha$. Proc Natl Acad Sci USA I 994, 9 I: I I 98-I 205.

16. Gutterman JU, Blumenschein GR, Alexanian R, Yap HY, Buzdar AU, Cabanillas F, Hortobagyi GN, Hersh EM, Rasmussen SL, Harmon M, Kramer M, Pestka S: Leukocyte interferon-induced tumor regression in human metastatic breast cancer, multiple myeloma, and malignant lymphoma. Ann Intern Med 1980, 93:399-406.

17. Gutterman JU, Fine S, Quesada J, Horning SJ, Levine JF, Alexanian R, Bernhardt L, Kramer M, Spiegel H, Colburn W, Trown P, Merigan T, Dziewanowski Z: Recombinant leukocyte A interferon: Pharmacokinetics, single-dose tolerance, and biologic effects in cancer patients. Ann Intern Med 1982, 96:549-556.

18. Rebouillat $D$, Hovanessian AG: The human 2',5'-oligoadenylate synthetase family: Interferon-induced proteins with unique enzymatic properties. J Interferon Cytokine Res 1999, 19:295-308.

19. Suhadolnik RJ, Sawada T, Gabriel J, Reichenbach NL, Henderson EE: Accumulation of low molecular weight DNA and changes in chromatin structure in HeLa cells treated with human fibroblast interferon. J Biol Chem 1984, 259:4764-4769.

20. Konno-Sato S, Wu JM, Carter TH: Phosphorylation of a 72-kDa nucleoprotein (NP-72) in HL-60 cells is mediated by the double-stranded DNA-dependent protein kinase (DNA-PK). Biochem Mol Biol Int 1993, 31: I 3-124.

21. Anderson CW, Lees-Miller SP: The nuclear serine/threonine protein kinase DNA-PK. Crit Rev Eukaryot Gene Expr 1992, 2:283-3|4.

22. Kramer G, Steiner GE, Sokol P, Handisurya A, Klingler HC, Maier U, Foldy M, Marberger M: Local intratumoral tumor necrosis factor-alpha and systemic IFN-alpha2b in patients with locally advanced prostate cancer. J Interferon Cytokine Res 200I, 21:475-484.

23. Maitake Products Inc: D-fraction obtained IND for clinical study. Corporate Publication 1998.
24. Mordente JA, Konno S, Chen Y, Wu JM, Tazaki H, Mallouh C: The effects of brefeldin A (BFA) on cell cycle progression involving the modulation of the retinoblastoma protein (PRB) in PC-3 prostate cancer cells. J Urol 1998, 159:275-279.
Publish with Biomed Central and every scientist can read your work free of charge

"BioMed Central will be the most significant development for disseminating the results of biomedical research in our lifetime. "

Sir Paul Nurse, Cancer Research UK

Your research papers will be:

- available free of charge to the entire biomedical community

- peer reviewed and published immediately upon acceptance

- cited in PubMed and archived on PubMed Central

- yours - you keep the copyright 